\title{
Clinical and Survival Outcomes in Patients with Supra-Diaphragmatic Vs Infra-Diaphragmatic Diffuse Large B Cell Lymphoma
}

${ }^{1}$ Akdeniz University, Faculty of Medicine, Department of Internal Medicine,

Division of Hematology, Antalya, Turkey.

${ }^{2}$ Medstar Antalya Hospital, Clinic of Hematology, Antalya, Turkey

\section{${ }^{1}$ Utku Iltar, ${ }^{1}$ Unal Atas, ${ }^{1}$ Ece Vural, ${ }^{1}$ Fadime Nurcan Alhan, ${ }^{1}$ Orhan Kemal Yucel, ${ }^{1}$ Ozan Salim, ${ }^{1}$ Levent Undar, ${ }^{2}$ Burak Deveci}

\section{Abstract}

Limited-stage diffuse large B-cell lymphoma (DLBCL) accounts for approximately $30 \%$ of all DLBCL cases. This study aimed to investigate the impact of the lymphoma involvement side relative to the diaphragm on clinical and survival outcomes in patients with limited-stage DLBCL treated with first-line rituximab, cyclophosphamide, doxorubicin, vincristine, and prednisone (R-CHOP). Data from 93 patients with limited-stage DLBCL between 2010 and 2019 receiving R-CHOP were retrospectively analyzed. Patients were divided into two subgroups according to the side of the diaphragm: 29 patients with infradiaphragmatic (InD) and 64 patients with supradiaphragmatic (SpD). There were no significant differences in survival outcomes [5-year PFS rate of SpD and $\mathrm{InD}$ groups, $76.7 \%$ and $85.7 \%$, respectively $(\mathrm{P}=0.553)$ 5 -year OS rates of SpD and InD groups, $82.1 \%$ and $89.1 \%$, respectively $(\mathrm{P}=0,524)$ ] and clinical characteristics, except that extra nodal involvement was dominant in the InD group and the SpD group had a higher IPI. In conclusion, in early-stage DLBCL, extra nodal involvement is expected more if the primary involvement area is below the diaphragm, however whether the primary involvement area is below or above the diaphragm has no effect on survival outcomes. The results of this study need to be confirmed by further studies with a larger case group.

Keywords: Infradiaphragmatic, supradiaphragmatic, diffuse large B-cell lymphoma, prognosis.

\section{Özet}

Erken evre diffüz büyük B hücreli lenfoma (DBBHL), tüm DBBHL olgularının yaklaşık \%30’unu olușturur. Bu çalışma, birinci basamak rituksimab, siklofosfamid, doksorubisin, vinkristin ve prednizon (R-CHOP) ile tedavi edilen erken evre DBBHL tanll hastalarda diyaframa göre lenfoma tutulum tarafının klinik ve sağkalım sonuçları üzerine etkisini araștırmayı amaçladı. 2010 ve 2019 yılları arasında R-CHOP alan erken evreli 93 DBBHL tanılı hastadan veriler geriye dönük olarak analiz edildi. Hastalar diyafram tarafına göre iki alt gruba ayrıldı: 29 infradiyafragmatik (InD) ve 64 supradiyafragmatik (SpD) hasta. Sağkalım sonuçlarında anlamlı bir fark yoktu [SpD ve InD gruplarının 5 yıllık PFS oranı, sirasıyla \%76.7 ve \%85.7 ( $\mathrm{P}=0.553)$; $\mathrm{SpD}$ ve InD gruplarının 5 yıllık OS oranları, sirasıyla \%82.1 ve \%89,1 $(\mathrm{P}=0,524)$ ]. Ayrıca, klinik özellikler açısından InD grupta ekstra nodal tutulumun baskın olması ve SpD grupta daha yüksek IPI mevcut olması dıșında anlamlı farklılık yoktu. Sonuç olarak, erken evre DBBHL'de, tutulum alanı diyaframın altındaysa ekstra nodal tutulum daha fazla beklenir, ancak tutulum alanının diyaframın altında veya üstünde olmasının sağkalım sonuçları üzerine etkisi yoktur. Bu sonuçlarının daha geniş bir hasta grubuyla yapılacak yeni çalıșmalarla doğrulanması gerekmektedir.

Anahtar Kelimeler: İnfradiyafragmatik, supradiyafragmatik, diffüz büyük B hücreli lenfoma, prognoz. 


\section{Introduction}

Diffuse large B-cell lymphoma (DLBCL) is the most common histologic subtype of nonHodgkin lymphoma (NHL). The staging of DLBCL is based on the Lugano modification of the Ann Arbor system ${ }^{1}$. This staging system focuses on the extent of tumor spread. For example, stage I refers to lymphoma found in 1 lymph node region or lymphoma invading 1 extralymphatic organ or site but not any lymph node regions. Stage II refers to lymphoma in 2 or more lymph node regions on the same side of the diaphragm. However, it does not consider whether it is above or below the diaphragm.

It was previously suggested that there may be differences in patient characteristics and treatment outcomes depending on whether the lymphoma involvement site is above or below the diaphragm, and some studies have addressed this point. Most of the studies reporting comparisons of patient characteristics and treatment outcomes between the supradiaphragmatic (SpD) and infradiaphragmatic ( $\mathrm{InD})$ lesion groups were in Hodgkin lymphoma (HL) ${ }^{2-5}$. According to previous reports, patients with infradiaphragmatic HL have been shown to present with an unfavorable risk profile, including older age, predominantly male sex and unfavorable histological subtypes, and involvement of $>3$ lymph node areas. Additionally, some reports suggested a poor outcome in HL patients with $\mathrm{InD}$ lesions ${ }^{4}$. However, some other reports showed no significant differences in outcomes between these 2 groups ${ }^{2,6}$. While much more literature data are available for Hodgkin's disease on this topic, only few data are available for DLBCL thus far, which is inconsistent with previously reported HL data ${ }^{7}$. Regarding the prognostic significance of the involvement side relative to the diaphragm, new studies are needed in limited-stage DLBCL patients. To compare the pretreatment patient characteristics and survival outcomes of two cohorts of SpD and InD DLBCL patients, we conducted a retrospective study of de novo DLBCL patients treated with immunochemotherapy.

\section{Patients and Methods}

\section{Data source and patient selection}

A retrospective analysis was conducted in 93 patients with limited-stage DLBCL who were treated with front-line rituximab, cyclophosphamide, adriamycin, vincristine and prednisone (R-CHOP) or R-CHOP-like regimens at our institution between 2010 and 2019. Upfront radiation therapy was not performed for any patients. Patients were excluded if they had evidence of a coincident or prior indolent lymphoma, received only palliative management, or had another malignancy that was uncontrolled. Patients with primary testicular, primary central nervous system (CNS), primary mediastinal B cell, primary cutaneous diffuse large B-cell lymphoma leg type and intraocular lymphoma were excluded due to the unique biology and established poorer outcome of these entities. The baseline characteristics of all patients were documented. Baseline clinical, laboratory, pathology, and imaging information for each patient were obtained from their paper and/or electronic medical records. PET-CT scans and bone marrow biopsies were routinely performed for staging purposes. Clinical staging was performed according to the Ann Arbor system using data obtained from physical examination records, whole-body PET/CT, bone marrow aspiration, and biopsy. Official approval from the institutional review board was obtained before the start of the study.

\section{Definition of variables}

The database contains variables including age at diagnosis, year of diagnosis, treatment initiation date, sex, presence of B symptoms, Eastern Cooperative Oncology Group (ECOG) performance status (PS), clinical stage, primary site of involvement, serum lactate dehydrogenase level, outcome and survival time. Limited (early) stages were defined as stage I or II based on the Ann Arbor system. We classified the patients into a supradiaphragmatic $(\mathrm{SpD})$ lesion group and an infradiaphragmatic (InD) lesion group according to the location of the lesions. The presence of extranodal involvement and, if 
present, the location of extranodal areas was noted. Bulky disease was defined as a lymph node mass greater than $7,5 \mathrm{~cm}$ in diameter ${ }^{8}$. If data were available, we used Hans' algorithm requiring three antibodies [CD10, multiple myeloma oncogene 1 (MUM1), and polyclonal B-cell lymphoma 6 (BCL6)] to classify DLBCL into GCB and non-GCB (ABC) subtypes ${ }^{9}$. Follow-up information, including details on relapse and death, was also obtained. Overall survival was calculated from the date of the initiation of R-CHOP therapy to the date of the last follow-up or death. PFS was calculated from the date of the initiation of R-CHOP therapy to the date of progression, death, or last contact, whichever occurred first.

\section{Statistical analysis}

Continuous data were presented with mean \pm standard deviation (SD) or median (IQR: Q1-Q3). Categorical variables were presented with frequency (n) and percentage (\%) and analyzed with Pearson chi-square, Fisher's Exact test and Fisher-FreemanHalton test. The normality assumptions were controlled by the Shapiro-Wilk test. MannWhitney $U$ test and Independent t-test were used for analysis of non-normally and normally distributed numerical data, respectively. Survival curves were generated by the Kaplan-Meier method and the log-rank test was performed to compare overall and progression-free survival between the $\mathrm{InD}$ and $\mathrm{SpD}$ groups. Cox proportional hazards model was used to estimate HRs. Hazard ratio (HR), with corresponding 95\% confidence intervals (95\% CIs), was reported. Statistical analysis was made using IBM SPSS Statistics for Windows, Version 23.0 (IBM Corp., Armonk, NY). Two-sided p-value less than 0.05 was considered statistically significant.

\section{Results}

Of 93 patients with stage I and II DLBCL, 64 presented with supradiaphragmatic DLBCL, and 29 presented with infradiaphragmatic DLBCL. The clinical characteristics of the patients according to the primary site of disease are listed in Table 1. Patient characteristics were comparable between the two cohorts, although patients with $\mathrm{SpD}$ lesions exhibited a higher stage $(p=0.04)$ and patients with $\mathrm{InD}$ lesions exhibited a higher rate of extra-nodal lesions $(\mathrm{p}=0.002)$.

Table 1. Baseline characteristics of 93 patients according to the primary site of limited stage diffuse large B-cell lymphoma

\begin{tabular}{|c|c|c|c|}
\hline Variables & $\begin{array}{c}\text { Infradiaphragmatic } \\
(\mathrm{n}=29)\end{array}$ & $\begin{array}{c}\text { Supradiaphragmatic } \\
(n=64)\end{array}$ & $p$ \\
\hline Age (years), Mean $\pm S D$ & $58.59 \pm 11.07$ & $52.75 \pm 16.56$ & ${ }^{a} 0.087$ \\
\hline \multicolumn{4}{|l|}{ Gender, $n(\%)$} \\
\hline Male & $19(65.5)$ & $36(56.3)$ & \multirow[t]{2}{*}{${ }^{c} 0.400$} \\
\hline Female & $10(34.5)$ & $28(43.8)$ & \\
\hline \multicolumn{4}{|l|}{ Stage, $n(\%)$} \\
\hline I & $14(48.3)$ & $17(26.6)$ & \multirow[t]{2}{*}{${ }^{c} 0.040$} \\
\hline II & $15(51.7)$ & $47(73.4)$ & \\
\hline IPI, Median (Q1-Q3) & $1(1-2)$ & $1(0-2)$ & ${ }^{b} 0.197$ \\
\hline Unknown & $6(20.7)$ & $19(29.7)$ & \multirow[t]{5}{*}{${ }^{d} 0.138$} \\
\hline Low & $12(41.4)$ & $26(40.6)$ & \\
\hline Low-Int & $4(13.8)$ & $14(21.9)$ & \\
\hline High-Int & $7(24.1)$ & $4(6.3)$ & \\
\hline High & $0(0)$ & $1(1.6)$ & \\
\hline "B', symptom, $n$ (\%) & $10(34.5)$ & $15(23.4)$ & ${ }^{c} 0.266$ \\
\hline
\end{tabular}




\begin{tabular}{|c|c|c|c|}
\hline LDH, Median (Q1-Q3) & $232(192-307)$ & $231(189-297.5)$ & ${ }^{b} 0.842$ \\
\hline \multicolumn{4}{|l|}{ ECOG PS, $n(\%)$} \\
\hline 0-1 & $26(89.7)$ & $55(85.9)$ & \multirow[t]{2}{*}{${ }^{e} 0.748$} \\
\hline$\geq 2$ & $3(10.3)$ & $9(14.1)$ & \\
\hline GIS involvement, $n$ (\%) & $12(41.4)$ & $3(4.7)$ & ${ }^{e}<0.001$ \\
\hline Bulky lesion, $n$ (\%) & $4(13.8)$ & $8(12.5)$ & ${ }^{e} 0.999$ \\
\hline Extra-nodal lesions, $n(\%)$ & $18(62.1)$ & $18(28.1)$ & ${ }^{c} 0.002$ \\
\hline Ocular & $0(0)$ & $1(1.6)$ & ${ }^{e} 0.999$ \\
\hline Thyroid & $0(0)$ & $2(3.1)$ & ${ }^{e} 0.999$ \\
\hline Colon & $4(13.8)$ & $1(1.6)$ & ${ }^{e} 0.032$ \\
\hline Pleura & $0(0)$ & $3(4.7)$ & ${ }^{e} 0.549$ \\
\hline Gastric & $10(34.5)$ & $3(4.7)$ & ${ }^{e}<0.001$ \\
\hline Pulmonary & $0(0)$ & $4(6.3)$ & ${ }^{e} 0.306$ \\
\hline Bone & $1(3.4)$ & $2(3.1)$ & ${ }^{e} 0.999$ \\
\hline \multicolumn{4}{|l|}{ Cell of origin, $n(\%)$} \\
\hline GBC & $6(35.3)$ & $8(19.5)$ & \multirow[t]{2}{*}{${ }^{e} 0.311$} \\
\hline $\mathrm{ABC}$ & $11(64.7)$ & $33(80.5)$ & \\
\hline
\end{tabular}

No significant difference was detected in PFS or OS between patients with $\mathrm{SpD}$ and $\mathrm{InD}$ groups. 5-year PFS rate of patient with $\mathrm{InD}$ group was $85.7 \%$ and mean PFS was 107.81 months (95\% CI: 92.42-123.21); 5-year PFS rate of patient with $\mathrm{SpD}$ group was $76.7 \%$ and mean PFS was 103.42 months (95\% CI:
90.89-115.95); $\quad$ Log-rank $=0.352, \quad p=0.553$; Fig. 1(A). 5-year OS rate of patient with InD group was $89.1 \%$ and mean OS was 107.1 months (95\% CI: 91.17-123.03); 5-year OS rate of patient with $\mathrm{SpD}$ group was $82.1 \%$ and mean OS was 104.31 months $(95 \%$ CI: 92.03 116.58); Log-rank=0.405, p=0.524; Fig. 1(B).
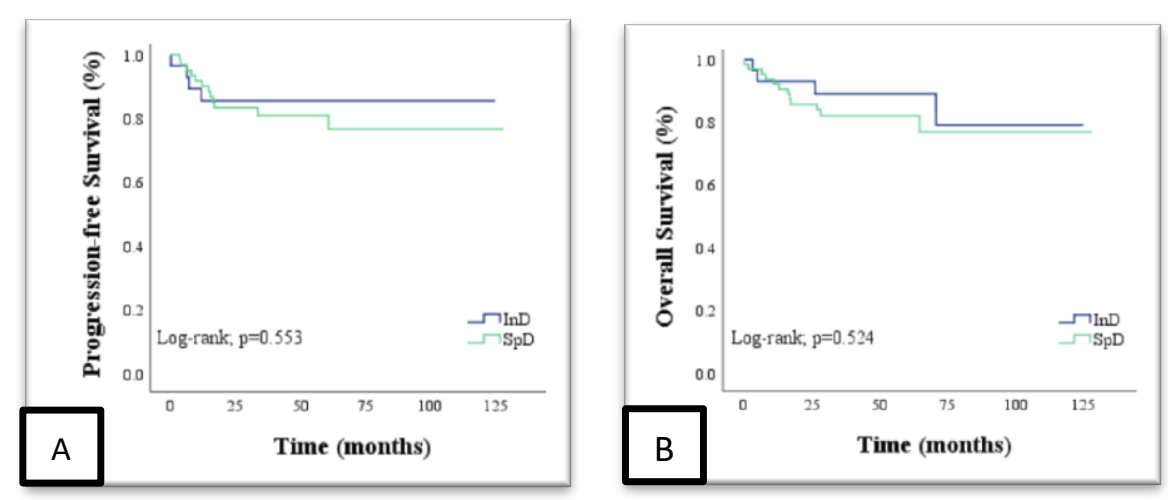

Figure 1. Survival curves of the two groups were compared using the log rank test. A. Progression-free survival (PFS) of patients with supradiaphragmatic (green line) and infradiaphragmatic (blue line) nodal disease. B. Overall survival (OS) of patients with supradiaphragmatic (green line) and infradiaphragmatic (blue line) nodal disease. 
An IPI of $2(\mathrm{P}=0.002)$, advanced age $(\mathrm{P}=$ 0.012), high LDH $(\mathrm{P}=0.010)$ and performance status $\geq 2(\mathrm{P}=0.004)$ were the clinical factors associated with poor 5-year PFS in univariate analysis (Table 2). With regard to 5-year OS, performance status $\geq 2$ $(\mathrm{P}<0.001)$, advanced age $(\mathrm{P}<0.001)$, high
LDH $(\mathrm{P}=0.019)$, B symptom $(\mathrm{P}=0.008)$, and higher IPI $(\mathrm{P}<0.001)$ were significant adverse prognostic factors in univariate analysis (Table 3). Multivariate Cox regression analysis of these risk factors revealed that OS was significantly worse in patients with advanced age.

Table 2. Cox regression analysis for progression free survival

\begin{tabular}{|c|c|c|c|c|c|c|}
\hline \multirow[t]{2}{*}{ Variables } & \multicolumn{2}{|c|}{ Relapse } & \multicolumn{2}{|c|}{ Univariate } & \multicolumn{2}{|l|}{ Multivariate } \\
\hline & $\begin{array}{c}\text { No } \\
\text { (n:77) }\end{array}$ & $\begin{array}{c}\text { Yes } \\
(\mathrm{n}: 16)\end{array}$ & HR $(95 \%$ CI $)$ & $\mathbf{p}$ & HR $(95 \%$ CI) & $\mathbf{p}$ \\
\hline \multicolumn{7}{|l|}{ Age } \\
\hline$M e a n \pm S D$ & $52.88 \pm 15.03$ & $62.69 \pm 14.01$ & $\begin{array}{c}1.052(1.011- \\
1.094)\end{array}$ & 0.012 & $\begin{array}{c}1.048(0.999- \\
1.099)\end{array}$ & 0.057 \\
\hline \multicolumn{7}{|l|}{ Gender } \\
\hline Male & $45(58.4)$ & $10(62.5)$ & Reference & & & \\
\hline Female & $32(41.6)$ & $6(37.5)$ & $\begin{array}{l}0.772(0.28- \\
2.128)\end{array}$ & 0.617 & & \\
\hline \multicolumn{7}{|l|}{ Group } \\
\hline İnfradiaphragmatic & $25(32.5)$ & $4(25)$ & Reference & & & \\
\hline Supradiaphragmatic & $52(67.5)$ & $12(75)$ & $\begin{array}{c}1.408(0.453- \\
4.378)\end{array}$ & 0.555 & & \\
\hline \multicolumn{7}{|l|}{ Stage } \\
\hline I & $29(37.7)$ & $2(12.5)$ & Reference & & Reference & \\
\hline II & $48(62.3)$ & $14(87.5)$ & $\begin{array}{c}4.097(0.931- \\
18.035)\end{array}$ & 0.062 & $3.753(0.8-17.61)$ & 0.094 \\
\hline \multicolumn{7}{|l|}{ IPI } \\
\hline Median (Q1-Q3) & $1(0-2)$ & $2(1-2)$ & $\begin{array}{c}1.901(1.197- \\
3.017)\end{array}$ & 0.006 & $\begin{array}{c}1.101(0.547- \\
2.218)\end{array}$ & 0.788 \\
\hline \multicolumn{7}{|l|}{ LDH } \\
\hline Median (Q1-Q3) & $\begin{array}{c}224(183- \\
295)\end{array}$ & $\begin{array}{c}260.5(214.5- \\
403.5)\end{array}$ & $\begin{array}{c}1.003(1.001- \\
1.005)\end{array}$ & 0.010 & $\begin{array}{c}1.003(0.999- \\
1.006)\end{array}$ & 0.122 \\
\hline \multicolumn{7}{|l|}{ ECOG PS } \\
\hline $0-1$ & 70(90.9) & $11(68.8)$ & Reference & & Reference & \\
\hline$\geq 2$ & $7(9.1)$ & $5(31.3)$ & $\begin{array}{c}4.779(1.635- \\
13.968)\end{array}$ & 0.004 & $0.951(0.16-5.646)$ & 0.951 \\
\hline \multicolumn{7}{|l|}{ Extra-nodal lesion } \\
\hline No & $46(59.7)$ & $11(68.8)$ & Reference & & & \\
\hline Yes & $31(40.3)$ & $5(31.3)$ & $\begin{array}{l}0.712(0.247- \\
2.051)\end{array}$ & 0.530 & & \\
\hline \multicolumn{7}{|l|}{ Cell of origin } \\
\hline GBC & $13(28.9)$ & $1(7.7)$ & Reference & & & \\
\hline $\mathrm{ABC}$ & $32(71.1)$ & $12(92.3)$ & $\begin{array}{c}4.467(0.579- \\
34.446)\end{array}$ & 0.151 & & \\
\hline \multicolumn{7}{|l|}{ Bulky lesion } \\
\hline No & $68(88.3)$ & $13(81.3)$ & Reference & & & \\
\hline Yes & $9(11.7)$ & $3(18.8)$ & $\begin{array}{c}1.611(0.459- \\
5.658)\end{array}$ & 0.456 & & \\
\hline
\end{tabular}




\begin{tabular}{|c|c|c|c|c|c|c|}
\hline \multicolumn{7}{|c|}{ 'B'" symptom } \\
\hline No & $59(76.6)$ & $9(56.3)$ & Reference & & Reference & \\
\hline Yes & $18(23.4)$ & $7(43.8)$ & $\begin{array}{c}2.559(0.951- \\
6.883)\end{array}$ & 0.063 & $\begin{array}{c}0.949(0.262- \\
3.441)\end{array}$ & 0.937 \\
\hline \multicolumn{7}{|c|}{ GIS involvement } \\
\hline No & $64(83.1)$ & $14(87.5)$ & Reference & & & \\
\hline Yes & 13(16.9) & $2(12.5)$ & $\begin{array}{c}0.693(0.158- \\
3.053)\end{array}$ & 0.628 & & \\
\hline
\end{tabular}

ABC, activated B-cell; ECOG PS, Eastern Cooperative Oncology Group Performance Status; GCB, germinal center B-cell; IPI, International Prognostic Index; LDH, lactate dehydrogenase.

Table 3. Cox regression analysis for overall survival

\begin{tabular}{|c|c|c|c|c|c|c|}
\hline \multirow[t]{2}{*}{ Variables } & \multicolumn{2}{|c|}{ Mortality } & \multicolumn{2}{|c|}{ Univariate } & \multicolumn{2}{|c|}{ Multivariate } \\
\hline & $\begin{array}{c}\text { No } \\
\text { (n:77) }\end{array}$ & $\begin{array}{c}\text { Yes } \\
(n: 16)\end{array}$ & HR $(95 \%$ CI) & $\mathbf{p}$ & HR (95\% CI) & $\mathbf{p}$ \\
\hline \multicolumn{7}{|l|}{ Age } \\
\hline$M e a n \pm S D$ & $51,86 \pm 14,29$ & $67,63 \pm 13,11$ & $\begin{array}{c}1,094(1,044- \\
1,146)\end{array}$ & $<0,001$ & $\begin{array}{c}1,057(1,002- \\
1,116)\end{array}$ & 0,043 \\
\hline \multicolumn{7}{|l|}{ Gender } \\
\hline Male & $46(59,7)$ & $9(56,3)$ & Reference & & & \\
\hline Female & $31(40,3)$ & $7(43,8)$ & $\begin{array}{c}0,984(0,364- \\
2,658)\end{array}$ & 0,975 & & \\
\hline \multicolumn{7}{|l|}{ Group } \\
\hline İnfradiaphragmatic & $25(32,5)$ & $4(25)$ & Reference & & & \\
\hline Supradiaphragmatic & $52(67,5)$ & $12(75)$ & $\begin{array}{c}1,442(0,464- \\
4,48)\end{array}$ & 0,527 & & \\
\hline \multicolumn{7}{|l|}{ Stage } \\
\hline I & $31(40,3)$ & $0(0)$ & Reference & & & \\
\hline II & $46(59,7)$ & $16(100)$ & $\begin{array}{c}41,93(0,604- \\
2909,349)\end{array}$ & 0,084 & & \\
\hline \multicolumn{7}{|l|}{ IPI } \\
\hline Median (Q1-Q3) & $1(0-2)$ & $2(1-3)$ & $\begin{array}{c}2,553(1,578- \\
4,132)\end{array}$ & $<0,001$ & $\begin{array}{c}1,068(0,503- \\
2,269)\end{array}$ & 0,864 \\
\hline \multicolumn{7}{|l|}{ LDH } \\
\hline Median (Q1-Q3) & $\begin{array}{c}230(184- \\
291)\end{array}$ & $\begin{array}{c}260,5(196- \\
412,5)\end{array}$ & $\begin{array}{c}1,003(1,001- \\
1,005)\end{array}$ & 0,019 & $\begin{array}{c}1,001(0,998- \\
1,005)\end{array}$ & 0,363 \\
\hline \multicolumn{7}{|l|}{ ECOG PS } \\
\hline $0-1$ & $73(94,8)$ & $8(50)$ & Reference & & Reference & \\
\hline$\geq 2$ & $4(5,2)$ & $8(50)$ & $\begin{array}{c}11,551(4,242- \\
31,452)\end{array}$ & $<0,001$ & $\begin{array}{c}4,177(0,659- \\
26,482)\end{array}$ & 0,129 \\
\hline \multicolumn{7}{|l|}{ Extra-nodal lesion } \\
\hline No & $47(61)$ & $10(62,5)$ & Reference & & & \\
\hline Yes & $30(39)$ & $6(37,5)$ & $\begin{array}{c}0,995(0,361- \\
2,739)\end{array}$ & 0,992 & & \\
\hline \multicolumn{7}{|l|}{ Cell of origin } \\
\hline GBC & $13(29,5)$ & $1(7,1)$ & Reference & & & \\
\hline $\mathbf{A B C}$ & $31(70,5)$ & $13(92,9)$ & $\begin{array}{c}6,035(0,772- \\
47,181)\end{array}$ & 0,087 & & \\
\hline
\end{tabular}




\begin{tabular}{|c|c|c|c|c|c|c|}
\hline No & $67(87)$ & $14(87,5)$ & Reference & & & \\
\hline Yes & $10(13)$ & $2(12,5)$ & $\begin{array}{c}0,985(0,224- \\
4,341)\end{array}$ & 0,984 & & \\
\hline \multicolumn{7}{|c|}{ 'B' symptom } \\
\hline No & $61(79,2)$ & $7(43,8)$ & Reference & & Reference & \\
\hline Yes & $16(20,8)$ & $9(56,3)$ & $\begin{array}{c}3,801(1,411- \\
10,241)\end{array}$ & 0,008 & $\begin{array}{c}0,886(0,216- \\
3,635)\end{array}$ & 0,867 \\
\hline \multicolumn{7}{|c|}{ GIS involvement } \\
\hline No & $64(83,1)$ & $14(87,5)$ & Reference & & & \\
\hline Yes & $13(16,9)$ & $2(12,5)$ & $\begin{array}{c}0,755(0,171- \\
3,325) \\
\end{array}$ & 0,710 & & \\
\hline
\end{tabular}

\section{Discussion}

In our study, we found that patients with $\mathrm{InD}$ and SpD lesions have similar PFS and OS and similar distributions of clinical features. Among the two groups classified by primary site, only extranodal disease and stage were different. The $\mathrm{SpD}$ group contained a predominance of stage II. The InD group contained a predominance of extranodal disease. To date, only one study has specifically evaluated the prognostic impact of primary regions by location in the $\mathrm{InD}$ region versus the $\mathrm{SpD}$ region in limited-stage DLBCL. As found in our study, Nakajima et al. ${ }^{7}$ reported that patients with $\mathrm{InD}$ and $\mathrm{SpD}$ lesions treated with R-CHOP therapy have similar PFS and OS in limited-stage DLBCL. Additionally, Nakajima et al. reported a similar distribution between these two groups regarding the clinical features; only $\mathrm{B}$ symptoms presented more frequently in the InD group.

In addition, Abdulla et al. ${ }^{10}$ reported a study that provides data on InD DLBCL. Patients with abdominal lymph node involvement were compared with those without abdominal lymph node involvement; however, all stages of DLBCL were included in the study. The clinical characteristics and survival outcomes of the patients were evaluated. Patients with abdominal lymph node involvement more often had bulky disease, B symptoms, a higher age-adjusted IPI, a higher stage and more frequent double expression of MYC and BCL2 than patients with no lymph node involvement in the abdomen. Patients with abdominal lymph node involvement had significantly inferior lymphoma-specific survival compared to patients without abdominal lymph node involvement, while there were no significant differences in OS or PFS between these two groups. However, abdominal lymph node involvement did not remain an independent prognostic factor in multivariate survival analyses.

Since, by definition, there is involvement above and below the diaphragm in advancedstage DLBCL, especially in stage 3, abdominal involvement is expected in the majority of this patient group. Therefore, when comparing patients with and without abdominal involvement, regardless of the lymphoma stage, investigating advanced stage and high IPI in patients with abdominal involvement may introduce a bias. In other words, since patients with abdominal involvement have an extra involvement area compared to those without abdominal involvement, advanced stage and therefore high IPI can be expected to occur more frequently. Therefore, we included only limited stage patients in the analysis to avoid selection bias from using data from all patients, including advanced stage patients.

Extranodal disease was more common in the InD group. In particular, GIS involvement was prominent among extranodal areas $(\mathrm{P}<0.001)$. Due to the widespread lymphoid structure around the GIS and its own structure, extranodal tissue invasion may be a possible reason, which is easier in the GIS. Many other studies investigating extranodal 
disease have similarly reported that extranodal involvement is more common in the $\mathrm{GIS}^{5,11,12}$.

The InD group accounted for $31.5 \%$ of all cases of clinical stage I/II DLBCL, a finding comparable with other studies. While approximately $5-10 \%$ of patients with earlystage HL present with InD disease at initial diagnosis, Nakajima et al. ${ }^{7}$ and Abdulla et al. 10 reported this rate in DLBCL as $39 \%$ and $22 \%$, respectively. Compared to $\mathrm{HL}$, a higher rate of $\mathrm{InD}$ lesions has been reported in DLBCL patients. Unlike NHL, HL commonly spreads through contiguous groups of lymph nodes ${ }^{13}$. Since the patterns of disease spread in HL and NHL are different, it is not surprising that the incidence of isolated $\mathrm{InD}$ involvement is higher in patients with DLBCL.

\section{REFERENCES}

1. Cheson BD, Fisher RI, Barrington SF, et al. Recommendations for initial evaluation, staging, and response assessment of hodgkin and nonhodgkin lymphoma: The lugano classification. $J$ Clin Oncol. 2014;32:3059-67.

2. Darabi K, Sieber M, Chaitowitz $M$, et al. Infradiaphragmatic versus supradiaphragmatic Hodgkin lymphoma: a retrospective review of 1114 patients. Leuk Lymphoma. 2005;46):171520.

3. Sasse S, Goergen H, Pl A, et al. Outcome of Patients With Early-Stage Infradiaphragmatic Hodgkin Lymphoma: A Comprehensive Analysis From the German Hodgkin Study Group. J Clin Oncol. 2018;36:2603-11.

4. $\mathrm{Km} \mathrm{K}$, Enblad $\mathrm{G}$, Gustavsson $\mathrm{A}$, et al. Infradiaphragmatic Hodgkin ' $\mathrm{s}$ disease: the Swedish National Care Programme. Eur $J$ Haematol. 1997;59:31-7.

5. Hui D, Proctor B, Donaldson J, et al. Prognostic implications of extranodal involvement in patients with diffuse large B-cell lymphoma treated with rituximab and cyclophosphamide, doxorubicin , vincristine, and prednisone. Leuk Lymphoma. 2010;51:1658-67.

6. Hospital G, Clinic H, Cancer $\mathrm{T}$, et al. Pure infradiaphragmatic Hodgkin's lymphoma. Clinical features, prognostic factors and comparison with supradiaphragmatic disease. Haematologica. 2006;91:32-39.

7. Nakajima Y, Tomita N, Itabashi M, et al. Analysis of outcomes in patients with supra-diaphragmatic vs infra-diaphragmatic diffuse large $\mathrm{B}$ cell lymphoma treated with R-CHOP therapy. Leuk Res. 2015;39:198-203.

8. Network NCC.National Comprehensive Cancer Network (NCCN) Guidelines B-Cell Lymphoma.
Retrospective design and limited patient number of the study which possibly limit the relevance of the results however, the long follow-up time and the homogeneity of selected patients according to stage and management gave reliability to our results. Nevertheless, additional examination of a larger set of cases is necessary in order to assess the prognostic relevance of the involvement side relative to the diaphragm in limited-stage DLBCL patients.

\section{Conclusion}

SpD localization was associated with a higher stage and $\mathrm{InD}$ localization with a higher rate of extra-nodal lesions. Even if these few differences in clinical presentation exist between $\mathrm{SpD}$ and $\mathrm{InD}$ limited-stage DLBCL, $\mathrm{SpD}$ or InD localization had no effect on PFS or OS.

2021 May 212021 [cited; Available from: https://www.nccn.org/professionals/physician_gls/ pdf/b-cell.pdf. B-Cell Lymphomas. Published online 2020.

9. Hans CP, Weisenburger DD, Greiner TC, et al. Confirmation of the molecular classification of diffuse large B-cell lymphoma by immunohistochemistry using a tissue microarray. Blood. 2004;103:275-82.

10. Abdulla M, Guglielmo P, Hollander P, Ahlström $\mathrm{H}$, Enblad G. Prognostic impact of abdominal lymph node involvement in diffuse large B-cell lymphoma. Eur J Haematol. 2020;104:207-13.

11. Castillo JJ, Winer ES, Olszewski AJ. Sites of extranodal involvement are prognostic in patients with diffuse large B-cell lymphoma in the rituximab era: An analysis of the Surveillance, Epidemiology and End Results database. Am J Hematol. 2014;89:310-14.

12. Armando Lo'pez-Guillermo, Luis Colomo, Mo'nica Jiménez, Francesc Bosch, Neus Villamor, Leonor Arenillas, Ana Muntanola, Silvia Montoto, Eva Giné, Dolors Colomer, Silvia Beà EC. Diffuse Large B-Cell Lymphoma: Clinical and Biological Characterization and Outcome According to the Nodal or Extranodal Primary Origin. J Clin Oncol. 2005;23:2797-2804.

13. Chairman PPC, Kaplan HS, Musshoff K, Smithers DW, Tubiana M. Report of the Committee on Hodgkin ' s Disease Staging Classification. Cancer Res . 1971;31:1860-61. 